\title{
The significance of agricultural input trade in global food production
}

\author{
Jyrki Niemi \\ MTT Taloustutkimus, Latokartanonkaari 9,00790 Helsinki,jyrki.niemi@mtt.fi
}

\begin{abstract}
During the last 40 years, we have seen that despite a doubling of global population, agricultural production has expanded faster still, suggesting that global food security has increased. The volume of cereals production has more than doubled and world meat production has more than quadrupled, for example. The traded volumes of food products have been expanding even more rapidly than world's output. Since 1960, each 1 percent increase in food output has been accompanied by 3 percent trade increase. Consequently, the economic value of food products traded worldwide has increased almost thirty-fold since the 1960s to equal over USD 1,020 billion by 2010. In other words, agriculture's worldwide dependence on trade has been increasing in spite of the impediments to agri-food trade erected over the years by national governments.

Trade expansion in agricultural commodities and food products has been accompanied by significant increases in agricultural input trade, such as fertilizers, pesticides, farm machinery, feedstuffs and genetic material. This paper attempts to increase our understanding of the structure and characteristics of international trade in agricultural inputs and to provide a historical perspective on the extent and direction of global trade in agricultural inputs. A general discussion of the factors which influence the magnitude and changes of agricultural input trade flows is also included.

Global trade in agricultural inputs occupies a special niche in the discussion and analysis of international agricultural trade. Trade in agricultural inputs arises partly because of the geographic disparity between agricultural input manufacturing and mining activities and the production of agricultural commodities. Just as the location of agricultural cropland and the production of agricultural commodities are unevenly distributed around the world, so is the production of agricultural inputs. The specific agricultural inputs examined here are fertilizers, pesticides, feedstuffs and agricultural machinery.

The empirical analysis of the study will be conducted with a sample of annual data that cover international trade flows in agricultural inputs from 1961 to 2009 . Volume and value statistics by country on imports and exports of fertilizers, pesticides, agricultural machinery and foodstuffs are obtained from FAOSTAT and COMTRADE, supplemented with individual country sources as required to fill gaps.

The results show that expansion of the global food market has resulted in a reshuffling of resources over the entire globe, providing food and livelihood possibilities where they may have been previously limited, unavailable or untenable (e.g. food provision to cities, or the development of animal production through imports of feed inputs). This market expansion has been accompanied by significant increases in agricultural input trade, such as fertilizers, pesticides, farm machinery, and genetic material. The major exporters of fertilizers are those countries with energy-rich resources or mineral reserves. In the case of pesticides and farm machinery, the major developed countries of North America and Western Europe tend to be major input exporters. This is due to their manufacturing infrastructure and heavy commitment to public and private research and development expenditure.
\end{abstract}

Key words: agriculture, inputs, production, trade, world. 


\section{Introduction}

During the last 40 years, we have seen that despite a doubling of global population, agricultural production has expanded faster still, suggesting that global food security has increased. The Green Revolution in the 1960s initiated the industrialization of agricultural production worldwide and food production volumes have increased dramatically since then. The volume of cereals production has more than doubled and world meat production has more than quadrupled (FAOSTAT 2008), for example. The traded volumes of food products have been expanding even more rapidly than world's output. Since 1960, each 1 percent increase in food output has been accompanied by 3 percent trade increase. Consequently, the economic value of food products traded worldwide has increased almost thirty-fold since the 1960 s to equal USD 1,020 billion by 2010 (FAOSTAT 2011). In other words, agriculture's worldwide dependence on trade has been increasing in spite of the impediments to agri-food trade erected over the years by national governments.

Trade expansion in agricultural commodities and food products has been accompanied by significant increases in agricultural input trade, such as fertilizers, pesticides, farm machinery, feedstuffs and genetic material. The use of intensive inputs in agriculture and access to plentiful fossil energy has enabled an increase in food production and standard of living, providing food and livelihood possibilities where they may have been previously limited, unavailable or untenable (e.g. food provision to cities, or the development of animal production through imports of feed inputs). The Green Revolution, in particular, led to the increasing use of high yielding seeds, fertilizers and chemicals as well as diesel and electricity. As a result, imported inputs take significant share in the production system of modern agriculture (Deutsch 2004).

Global trade in agricultural inputs occupies a special niche in the discussion and analysis of international agricultural trade. Trade in agricultural inputs arises partly because of the geographic disparity between agricultural input manufacturing and mining activities and the production of agricultural commodities (Daberkow and Parks 1990). Just as the location of agricultural cropland and the production of agricultural commodities are unevenly distributed around the world, so is the production of agricultural inputs.

This paper attempts to increase our understanding of the structure and characteristics of international trade in agricultural inputs and to provide a historical perspective on the extent and direction of global trade in agricultural inputs. A general discussion of the factors which influence the magnitude and changes of agricultural input trade flows is also included. The specific agricultural inputs examined here are fertilizers, pesticides, feedstuffs and agricultural machinery.

The empirical analysis of the study will be conducted with a sample of annual data that cover international trade flows in agricultural inputs from 1961 to 2009. Volume and value statistics by country on imports and exports of fertilizers, pesticides, agricultural machinery and foodstuffs are obtained from FAOSTAT (2011) and COMTRADE (2011), supplemented with individual country sources as required to fill gaps. Volume data is compiled in metric tons, and value data in US dollars. The transaction value is the value at which goods were bought by the importing country and includes the cost of transportation, insurance, and freight to the frontier of the importing country (c.i.f. valuation).

\section{Factors affecting agricultural input trade}

International trade is founded on the principle that open markets allow countries to specialise in producing the goods or services in which they have a 'comparative advantage'. This theory outlined by David Ricardo (1817) demonstrates that a country will be better off if, rather than producing everything it consumes, it specializes in producing goods and services in which it is particularly productive. This advantage might occur because of climate, natural resources, plentiful land or labour, specialist knowledge or so on. It can then trade its surplus of these goods with other countries to obtain other goods it wishes to consume. With specialisation and trade, the country is able to consume more than it would have done if it had consumed only what it produced (i.e. $100 \%$ self sufficient).

The concept of comparative advantage is often used to explain why country or region produces (and possibly exports) or imports an agricultural input or agricultural commodity. A country's endowment of natural resources, such as phosphate rock, or potash, is an obvious determinant of crude or manufactured fertilizer production and trade. A highly developed manufacturing infrastructure, such as is found in countries producing significant amounts of farm machinery and pesticides, influ- 
ences trade flows of these products. In other cases, such as herbicides and plant and animal genetic material, a heavy commitment to public and private research and development is correlated with input production and export (Daberkow and Parks 1990).

One of the key factors driving the use of aggregate agricultural input is the amount of area devoted to cropland. Worldwide cropland area of the major crops increased about 8 percent between 1960 and 2009. Much of the world's cereal cropland in 2009 was located in Asia (34 \%), Africa (16 $\%$ ), Northern America (15\%), and Eastern Europe (14\%). However, due to differing intensities of input use and crop mixes, the actual production of cereals showed a somewhat different distribution. Asia produced slightly over $44 \%$ of the world's cereals, followed by Northern America (22\%) Eastern Europe ( $8 \%$ ), and Africa (7\%).

Fertilizer consumption, the best documented input use statistics, reflects the world's geographic distribution of cereal land and input use intensity. World use of fertilizers increased about 275 (in terms of nutrients) per cent between 1980 and 2009, use in Asia quadrupled, and the use in South America tripled. Concomitantly, Asia's share of world fertilizer consumption grew from 32 percent in 1980 to 64 percent in 2009, while the North America decreased its share from 24 percent in 1980 to 12 percent in 2009.

Therefore, Asia produced about 44 percent of the world's cereals with 64 percent of the fertilizers, while Northern America produced 22 percent of the cereal production but consumed only 12 percent of all fertilizers. Crop mix, the extent of non-cereal commodity production, relative input and output prices, climate, available technology, and soil nutrient requirements vary considerably between Asia and Northern America.

\section{Global trade in agricultural inputs}

The value of global farm fertilizer trade increased from around USD 13 billion in 1980 to over USD 20 billion in 2009. World trade in crude fertilizers, which is primarily phosphate rock, increased more than six-fold in value from 1960 to 1989, but has trended downwards since then. In 2009 the value of crude fertilizer exports were less than USD 1.5 billion, approximating the trade levels of the early 1970's. This indicates stagnating trade flows as more phosphate rock is processed rather than shipped in raw form. Africa and Eastern Europe, by virtue of their large deposits of phosphate rock dominate the export market for crude fertilizers. Western Europe has traditionally been the major importer of crude fertilizers with nearly one-half of the total value.

While crude fertilizer trade patterns depend upon the disparities between deposits of phosphate rock and the location of agricultural production, the trade in manufactured fertilizer is more complex. The production of manufactured fertilizers depends on such natural resources as natural gas, sulphur, and potash reserves and on manufacturing infrastructure. North America and Eastern Europe are leading exporters of manufactured fertilizers. Asian countries are the primary import markets, accounting for roughly $40 \%$ of the volume of world imports. North America and Western Europe are also major fertilizers importers, accounting for $19 \%$ and $16 \%$ of world imports, respectively.

Asia is a largest net importer of fertilizers primarily due to China, Thailand, India, Japan, and Malaysia. South America has also become a large net importer over the years. However, Asia's fertilizer self-sufficiency rate remains still around $90 \%$, while South America's fertilizer self-sufficiency rate is only around $43 \%$, down from $55 \%$ in the early 1990 's. Oceania's self-sufficiency rate in fertilizers has also been traditionally less than 60\%. Eastern Europe and Northern America are the largest net exporters of fertilizers with Russia, Belarus, Lithuania, Romania, the US, and Canada the major exporting countries.

International trade in pesticides products grew from around USD 4.5 billion in 1980 to over USD 25 billion in 2008. Pesticides manufacturing typically requires a sophisticated industrial infrastructure as well as heavy commitment to research and development. Hence, pesticides are only produced in a few countries. Western Europe has been the dominant pesticide exporter, accounting for between 40 and 50 percent of the value of all world exports. Asian countries account for about 20 percent of world pesticides exports. North America has historically exported 15 percent of the value of all pesticides.

Asia and Western Europe are also large pesticides importers, importing currently about 40 percent of all the traded pesticides. South America's share has increased from less than 4 percent in 1990 to about 15 percent in 2009. African, South American and Eastern European countries are the primary 
net importers of pesticides. Asian, Northern American and Western European countries are the largest net exporters with USA, China, India, Germany, France, and Belgium the major pesticides exporting countries.

In terms food security, pesticides together with veterinary medicines are critical, and if there is a plant or animal epidemic, several countries need to use these chemicals at the same time. Normally, there is no extra production capacity and also the raw materials for pesticides and medicals are not easy to get. Therefore, in crisis situations it will be very difficult to get large volumes of these chemicals.

The value of global farm machinery exports increased from around USD 13 billion in 1980 to over USD 40 billion in 2009. Farm machinery production, which includes tractors, harvesters and other agricultural machinery, is mainly located in the industrialized countries of Asia, North America and Western and Northern Europe. Western Europe has historically dominated the trade of farm machinery, accounting for nearly $40 \%$ of all exports in most years. Germany, France, and the Netherlands are the major exporting countries. The major importing regions are in North America, Western Europe, and Northern Europe. Africa, Oceania, Eastern and Northern Europe have historically been net importers of farm machinery. In terms of food security, the most critical in machinery imports are spare parts and their logistics, because spare parts are stored in a very few central storage in Europe and North America.

Protein feeds, especially soy, form a critical factor on the livestock production side. There are only three major producers of soy in the world: the US, Brazil, and Argentina. This means that all Asian and European countries need to import large amounts of soy to have efficient meat and milk production. Without soy, all broilers, $50 \%$ of pigs and $20 \%$ of cows in Europe would be without protein feed. The entire soy chain is vulnerable. Forty percent of the imports to Europe occur in Rotterdam and several oil pressing facilities are situated near Rotterdam. Although farms can replace soy with rapeseed, it's not as effective.

Concerning energy, and especially oil and gas, only few countries worldwide are self-sufficient. In Europe only Norway is nearly $100 \%$ self-sufficient. A couple of other European countries have their own production, but the rest need to import practically $100 \%$. In the future, some part of the oil used on farms could be bio based, but only on average of 10-30\%. Without energy security, the modern food systems are unlikely to enjoy food security, whatever its level of food self-sufficiency.

\section{Conclusions}

As the world's food production system has become more interdependent, trade in raw agricultural commodities, processed foods as well as agricultural inputs have grown steadily. Agriculture's worldwide dependence on trade has been increasing in spite of the impediments to trade erected over the years by national governments. The Green Revolution, in particular, initiated the industrialization of agricultural production worldwide and traded volumes of food products have increased dramatically since the 1960 's.

The expansion of the global food market has resulted in a reshuffling of resources over the entire globe, providing food and livelihood possibilities where they may have been previously limited, unavailable or untenable (e.g. food provision to cities, or the development of animal production through imports of feed inputs). This market expansion has been accompanied by significant increases in agricultural input trade, such as fertilizers, pesticides, farm machinery, and genetic material. Trade in agricultural inputs is essential to improve food security. Restrictions on international trade could jeopardize prospects for regional food security. 


\section{Literature}

Binkley, J. \& Connor, J. 1998. Grocery market pricing and the new competitive environment. Journal of Retailing 74: 273-294.

COMTRADE. 2011. UN Commodity trade statistics database. United Nations Statistics Division. Available at: http://unstats.un.org/unsd/comtrade/dqBasicQueryResults.aspx?cc=08142\&px=S2\&r.

Daberkow, S. \& Parks, J. 1990. Global trade in agricultural inputs. U.S. Department of Agriculture, Economic Research Service, Statistical Bulletin No. 812. 88 p.

Deutsch, L. 2004 Global trade, food production and ecosystem support: Making the interactions visible. Doctoral Thesis in Natural Resource Management, Department of Systems Ecology, Stockholm University.

FAOSTAT. 2011. Agricultural database collections by Food and Agriculture Organization of the United Nations, Rome. Available at: http://apps.fao.org/cgi-bin/nph-db.pl?subset=agriculture.

Ricardo, D. 1817. On the principles of political economy and taxation. Cambridge: Cambridge University Press, 1981. 